\title{
Phytophagous insects and web-building spiders in relation to pasture vegetation complexity
}

\author{
Paulo A. V. Borges and Valerie K. Brown
}

Borges, P. A. V. and Brown, V. K. 2001. Phytopahgous insects and web-building spiders in relation to pasture vegetation complexity. - Ecography 24: 68-82.

\begin{abstract}
We investigate the potential use of structural characteristics of vegetation as predictors of the densities of pasture arthropods in three Azorean islands. Two types of upland pastures, recent sown pastures (3-4 yr old) and wet semi-natural old pastures ( $>35 \mathrm{yr}$ old), were studied in three Azorean islands (S. Maria, Terceira and Pico). Three arthropod assemblages, of particular importance in pasture habitats, were assessed: insect forb-feeders, insect grass-feeders and web-building spiders. These are numerically abundant and represent a range of feeding strategies. Point quadrats for plants and suction (Vortis) for arthropods were used as sampling methods. Several vegetation indices were investigated, but only three (cover abundance of perennial forbs, cover abundance of perennial grasses and the total vegetation alpha-diversity) were good predictors of invertebrate abundance. Vegetation structure, defined by a Height Index, was of minor predictive value. In sown and semi-natural pastureland, diverse and structurally complex pasture sites support more individual insect forbfeeders, grass-feeders and web-building spiders per unit area than less complex ones.
\end{abstract}

P. A. V. Borges and V. K. Brown, NERC Centre for Population Biology, Imperial College, Silwood Park Ascot, Berks, U.K. SL5 7PY (present address of P. A. V. B.: Univ. dos Açores, Dept de Ciencias Agrárias, Terra-Chã, PL-9700 Angra do Heroismo, Terceira, Açores, Portugal, pborges@angra.uac.pt).

The role of herbivorous invertebrates in grassland dynamics has been considered subtle (Crawley 1990), while other studies have demonstrated that insect herbivory can be a major determinant of plant community structure and composition (Gange and Brown 1989, Brown et al. 1990, Brown and Gange 1992). Moreover, invertebrate herbivores are known to cause production losses in grassland systems (Henderson 1978, Curry 1994) and can significantly alter community composition and productivity in ecosystems (Huntly 1991, Tscharntke and Greiler 1995).

Grassland arthropod predators may also be important in shaping the community structure of their food source, including invertebrate herbivores (Strong et al. 1984, Siemann et al. 1998), but there is little strong evidence for this hypothesis (Stilling 1988, Curry 1994). For instance, there is no theory predicting when natural enemies will exert significant mortality in polycultures
(Andow 1991) and little evidence that spider populations cause significant density-dependent mortality in prey populations (Wise 1995).

The density and diversity of grassland invertebrates depends on a number of factors: 1) the abundance of invertebrates changes with the seasonal mean temperature in temperate grasslands (Usher 1978). Physical features of the environment (e.g. temperature, moisture) may, therefore, act directly on the physiology of the invertebrates, but may also have indirect effects through the supply of plant food and the quality of habitats (Curry 1994); 2) concentration of resources is also important (Strong et al. 1984). The "resource concentration hypothesis" (Root 1973) predicts that "herbivores are more likely to find and remain on hosts that are growing in dense or nearly pure stands". Thus, the abundance of specialist herbivores will be lower in polycultures, since it is less likely that they will be able

Accepted 14 March 2000

Copyright (C) ECOGRAPHY 2001

ISSN 0906-7590

Printed in Ireland - all rights reserved 
to locate their host-plant in a diverse mosaic (Bach 1980, Andow 1991). In practical terms, this model predicts that arthropod pest outbreaks are more likely to occur in monocultures than in polycultures (Andow 1991). Moreover, as specialist and generalist natural enemies are more diverse in polycultures (Root 1973, Bach 1980, Andow 1991), the "enemies hypothesis" (Root 1973) also predicts that herbivore population densities are lower in polycultures than in monocultures; 3) management of pastures has an important impact on arthropod species composition, density and diversity (e.g. Morris 1973, 1990a, b, c, Rushton et al. 1989, Brown et al. 1990, Good and Giller 1991, Dennis et al. 1998). Grazing induces changes in habitat structure that influence the diversity and density of pasture arthropods (Brown et al. 1992, Gibson et al. 1992a, b, Curry 1994). Plant species architecture (Lawton 1983, Stinson and Brown 1983, Strong et al. 1984, Haysom and Coulson 1998) and habitat structure (Southwood et al. 1979, Lawton and Strong 1981, Brown and Southwood 1987, Brown 1991a, b, Denno and Roderick 1991, Gardner et al. 1995) were shown to be important in determining the diversity and abundance of phytophagous insects. In fact, the relationship between diversity and habitat complexity is viewed as a general pattern in community ecology (Schluter and Ricklefs 1993). For instance, predators, such as web-building spiders, might be expected to have relatively predictable assemblages based on habitat structure (Uetz 1991, Gibson et al. 1992a, Wise 1995).

In this paper, we investigate the potential use of characteristics of the vegetation to predict the densities of pasture arthropods. Three groups of arthropod assemblages are investigated: insect forb-feeders, insect grass-feeders and web-building spiders, since these assemblages are the main groups in the pasture habitats studied, and present a range of feeding strategies. Webbuilding spiders are particularly suitable for this study, since they are expected to be directly dependent on vegetation structural complexity and respond to variation in plant architecture at very localized scales (Gibson et al. 1992a).

\section{Materials and methods}

\section{Sites and experimental design}

A detailed description of the sites is presented elsewhere (see Borges 1997, Borges and Brown 1999). In summary, two $900 \mathrm{~m}^{2}$ replicates of upland recently sown pastures (3-4 yr old) and upland wet semi-natural old pastures $(>35$ yr old) were selected in three Azorean islands (Santa Maria, Terceira and Pico). These pasture types are referred to as habitats. In order to manipulate and standardize the periods of cattle grazing, all the 12 sites ( 3 islands $\times 2$ habitats $\times 2$ replicates) were fenced during January and February 1994, with additional rabbit fences being erected in April 1994. In addition, in each of the $900 \mathrm{~m}^{2}$ replicates, $203 \times 3 \mathrm{~m}$ plots were demarcated. Because of the different geometry of the main pastures, the 12 field sites were of two shapes: seven had a $5 \times 4$ configuration of plots and five had three rows of eight plots, with the last four being omitted from sampling. All the fenced sites were grazed regularly by dairy and beef cattle, thereby maintaining the traditional management of the sites.

\section{Sampling}

Sampling occurred at least three weeks after a grazing period, to allow regrowth of the vegetation. Vegetation and arthropod data were collected in the spring, summer and autumn 1994 and summer 1995. The vegetation was sampled by point-quadrats and the arthropods by suction.

\section{Vegetation}

Vegetation was sampled using a frame, comprising ten equally-spaced vertical $3 \mathrm{~mm}$ diameter point-quadrat pins, as used by V. K. Brown and colleagues at Silwood Park (see also Gibson et al. 1987). In each of the 20 plots, two linear frames were placed at random. The number of touches of each living plant species was recorded in $2 \mathrm{~cm}(<10 \mathrm{~cm})$ or $5 \mathrm{~cm}$ (10 cm and above) height intervals, to provide a measure of sward architecture. Thus, a total of 400 pins was used for each field site on each sampling occasion.

Data were collated to give a range of measures:

\section{Cover abundance ( $\mathrm{ca}$ )}

Was calculated as the total number of touches of a species on 400 height-profile point-quadrat pins. This measure gives a reliable estimate of cover abundance (also referred to as cover) for a species (Brown et al. 1988), and can be related to biomass. As most forb and grass species in the sites were perennial, the perennial forb cover abundance (PEFca) and the perennial grass cover abundance (PEGca) were selected as potential explanatory variables of arthropod abundance.

\section{Height (ht)}

Is a measure of plant structure. The weighted mean height of the total vegetation (V-ht), of the perennial forbs (PEF-ht) and of the perennial grasses (PEG-ht) was calculated for each plot (20 pins) using the expression:

$$
\sum_{i=1}^{N}\left(h_{i} \times n_{i}\right) / \sum_{i=1}^{N}\left(n_{i}\right)
$$


where $h_{i}=$ the midpoint of the height class $i, n_{i}=$ number of touches at height class $\mathrm{i}$ and $\mathrm{N}=$ number of height classes represented in the sample (Gibson et al. 1987). Means were taken from 20 plots for each site on each sampling occasion.

William's $\alpha$ diversity $(W-\alpha)$

The index of plant diversity used was the William's $\alpha$ index $(\alpha)$ (see Southwood 1978):

$\mathrm{S}=\alpha \ln (1+\mathrm{N} / \alpha)$

Plant structural diversity was assessed from the multiple touch data, using the above formula where $\mathrm{S}$ was the summation of the number of species in each height class and $\mathrm{N}$ the total of number of touches in the sample (see Stinson and Brown 1983, Brown and Gange 1989). This index (W- $\alpha$ ) was only calculated for the total vegetation in each plot. Means were taken from 20 plots for each field site for each sampling occasion.

\section{Species richness}

The mean number of vascular plant species touching the point-quadrat pins ("Sprich") was used as a measure of plant species richness. Species touching all the pins in each plot are clearly the most frequent species in the sites. This measure was calculated for all vascular plant species and means were estimated from 20 plots for each site on each sampling occasion. In addition, two other measures of species richness were used: total forb species ("tFspp") and total grass species ("tGspp"). In both cases, species richness was obtained by pooling the 20 plots.

\section{Invertebrates}

A "Vortis" suction apparatus was used. Sampling was carried out between 11.00 and 18.00 on warm, sunny days when the vegetation was dry. In each of the 20 plots in each field site, four random subsamples were taken, one in each corner of the $3 \times 3 \mathrm{~m}$ square plots (a total area of $0.8 \mathrm{~m}^{2}$ ). The collection nozzle was held in position for $30 \mathrm{~s}$ on each occasion. To speed the sampling (important in the changeable weather in the Azores) and to simplify sorting, the four subsamples in a plot were taken successively without changing the collection vial. The samples were stored in $70 \%$ ethanol with glycerol prior to sorting.

The arthropod assemblages studied comprised: grassfeeders - all sucking and chewing herbivorous insect species reported to feed on grasses; forb-feeders - as above though reported to feed on forbs; web-building spiders - all species of Tetragnathidae, Araneidae, Linyphiidae, Theridiidae and Dictynidae. Dietary information for the insect herbivores was either taken from the literature or given by different specialists (see Acknowledgements). For the spiders, families were assigned to the web-building assemblage following Roberts (1995) and Wise (1995). The abundance of arthropods is given as the mean number of individuals $\mathrm{m}^{-2}$ in each field site. All specimens, including adults and juveniles, were included in estimates of species abundance. In Appendix 1, the abundance for a species was obtained taking the mean abundance in the four available samples per site. Only the samples where a species occurred were considered for calculation. As the frequency distribution of abundance within each species was shown to be right skewed, the geometric mean was chosen instead the arithmetic mean.

\section{Data analysis}

GLIM (Crawley 1993) procedures were used to investigate differences in the vegetation explanatory variables and in the arthropod abundance between sampling events, between islands nested within sampling events and between habitats nested within islands.

Multiple regressions were also performed using GLIM to obtain the minimal adequate model explaining the greatest variation in density of the three invertebrate groups. A maximal model was fitted, including the following explanatory variables: $\mathrm{W}-\alpha$, PEFca, PEFht, tFspp in predicting the abundance of forb-feeding insects; W- $\alpha$, PEGca, PEG-ht, tGspp in predicting the abundance of grass-feeding insects. A preliminary analysis indicated that the best variables in predicting the abundance of web-building spiders were W- $\alpha$, PEGca, V-ht and Sprich.

Model simplification was achieved by deleting nonsignificant terms from the model, until none could be removed without causing an increase in deviance with $p<0.05$. The response variables were consistently logarithmically transformed in order to equalize variance and improve normality of errors. Transformation (logarithmic or square root) of the explanatory variables was used where necessary to improve normality of errors.

The observations for the different sampling occasions arise from the same experimental plots and were not, therefore, independent. Thus, each sampling event was analysed independently. As will be shown below, there was a habitat effect in several of the response and explanatory variables. Thus, each habitat was also analysed independently. As there are three response variables (insect forb-feeding density, insect grass-feeding density and web-building spider density), two habitats (sown and semi-natural pastures) and four sampling occasions (spring, summer and autumn 1994, summer 1995), twentyfour $(3 \times 2 \times 4)$ multiple regression analyses were performed.

Results of analyses are expressed in tables, each composed of 16 probabilities (4 sampling periods $\times 4$ 
explanatory variables removed from each maximum models). Thus, to adjust for multiple comparisons we accepted the vegetation indices probabilities at a conservative Bonferroni-corrected $\alpha^{\prime}$ of 0.0031 .

Only six points and four degrees of freedom are available in each multiple regression. This is unavoidable because of the nature and extent of the study. The results are therefore discussed in terms of their biological relevance.

\section{Results}

A total of 73 species of vascular plants ( 52 forbs and 21 grasses) were sampled by point-quadrats in the 12 sites. Fourtythree forbs and 20 grasses were found in sown pastures, while in semi-natural pastures, there were 41 forbs and 17 grasses (for further details see Borges 1997, 1999).

In the suction samples, totals of 4408, 24394 and 24489 individual arthropods were identified and sorted into 51 species of forb-feeders, 21 grass-feeders and 29 web-building spiders respectively (see Appendix 1).

The values of the response and explanatory variables used as y-variables in nested analyses of variance and as $\mathrm{y}$ and $\mathrm{x}$-variables in multiple regressions are given in Appendix 2.

Only three variables showed a sampling date effect, namely V-ht $\left(\mathrm{F}_{3,8}=4.45, \mathrm{p}<0.05\right)$, PEF-ht $\left(\mathrm{F}_{3,8}=\right.$ 5.21, $\mathrm{p}<0.05)$ and PEG-ht $\left(\mathrm{F}_{3,8}=5.14, \mathrm{p}<0.05\right)$. There was no significant effect of island (nested within sampling event) or habitat (nested within island). This is a consequence of seasonal and between-year differences in the height of the sward due to climatic factors. In most sites, vegetation height peaked in the summer. The results did show a significant island effect for several variables. Vegetation diversity $(\mathrm{W}-\alpha)$ was slightly higher in S. Maria and lower in Terceira on all sampling occasions $\left(\mathrm{F}_{8,12}=2.83,0.05<\mathrm{p}<0.1\right)$, while the abundance of web-building spiders $\left(\mathrm{F}_{8,12}=4.13\right.$, $\mathrm{p}<0.05$ ) tended to be higher in Pico (spring and summer 1994) or Terceira (autumn 1994, summer 1995) and lower in S. Maria.

In two variables, there were both island and habitat effects: PEFca $\left(\mathrm{F}_{8,12}=3.14, \mathrm{p}<0.05 ; \mathrm{F}_{12,24}=2.66, \mathrm{p}<\right.$ 0.05 respectively) and the abundance of forb-feeding insects $\left(\mathrm{F}_{8,12}=5.07, \mathrm{p}<0.01 ; \mathrm{F}_{12,24}=2.16,0.05<\mathrm{p}<\right.$ 0.1 ). The result obtained with PEFca was because of a generally higher cover of forbs in the semi-natural pastures in S. Maria than Pico or Terceira. The abundance of forb-feeding insects was mainly higher in S. Maria than in the other two islands, but there were no consistent patterns between habitats.

The three remaining variables showed only a significant habitat effect. The species richness (alpha diversity) was consistently higher in the semi-natural pastures than in the sown pastures, but particularly so in S. Maria and Terceira $\left(\mathrm{F}_{12,24}=3.18, \mathrm{p}<0.01\right)$. Yet, overall (gamma diversity) more plant species were listed in the sown pastures than in the semi-natural pastures. The PEGca $\left(\mathrm{F}_{12,24}=4.86, \mathrm{p}<0.001\right)$ and the abundance of grass-feeding insects $\left(\mathrm{F}_{12,24}=5.27, \mathrm{p}<0.001\right)$ also showed a highly significant habitat effect. The abundance of grass-feeding insects was higher in the semi-natural pastures from S. Maria and Pico and in the sown pastures from Terceira, and the cover abundance of grasses tended to be higher in the semi-natural pastures of the three islands, with the greatest differences occurring in Terceira.

\section{Forb-feeding insects}

The forb-feeding insects found in the two habitats (see Appendix 1) varied in species abundance. They were dominated by legume-feeders, the aphids Acyrtosiphon pisum (Harris) (geomean abundance of $1.35 \mathrm{~m}^{2}$ in sown pastures and $1.10 \mathrm{~m}^{2}$ in semi-natural pastures) and Therioaphis trifolii (Monell) ( (own $=0.85 \mathrm{~m}^{2}$, semi-natural $=0.34 \mathrm{~m}^{2}$ ) and adults of the curculionid Sitona flavescens (Marshall) (sown $=0.37 \mathrm{~m}^{2}$, semi-natural $=$ $0.11 \mathrm{~m}^{2}$ ), resulting from the high cover abundance of Lotus uliginosus Schkuhr and Trifolium repens L. in most sites. Also common were the, aphids Thecabius affinis (Kaltenbach) (semi-natural $=0.75 \mathrm{~m}^{2}$ ) and Aphis craccivora Koch (sown $=0.34 \mathrm{~m}^{2}$ ), and the caterpillars, Cyclophora puppillaria granti Prout (semi-natural $=0.44$ $\mathrm{m}^{2}$ ) and Agrotis segetum (Denis and Schiffermuller) (semi-natural $=0.38 \mathrm{~m}^{2}$ ) (see Appendix 1).

The abundance of forb-feeding insects (AFF) in sown pastures was significantly positively correlated with the cover of perennial forbs (PEFca) in spring and autumn 1994, and with the diversity of the total vegetation $(\mathrm{W}-\alpha)$ in the summers of 1994 and 1995 (Table 1a). Significant negative correlations were obtained with total forb species (tFspp) in the spring and autumn 1994 (Table 1a).

Likewise, the abundance of forb-feeding insects (AFF) in semi-natural pastures was significantly positively correlated with PEFca in spring and autumn 1994, and with W- $\alpha$ in summer 1995 (Table 1b). Significant negative correlations were obtained with tFspp in spring and autumn 1994 (Table 1b).

\section{Grass-feeding insects}

The grass-feeding insect species (see Appendix 1) include grass foliage-chewing insects (Orthoptera, Lepidoptera), grass root-chewing insects (Lepidoptera Noctuidae and Coleoptera - Curculionidae) and leaf and root sap-feeders (Heteroptera - Miridae; Homoptera, Auchenorrhyncha - Cicadellidae and Del- 
Table 2. Abundance of grass-feeding insects in sown (a) and semi-natural (b) pastures; analysis of deviance (ANODEV) table for multiple regression with step-wise omission of nonsignificant terms, beginning from the maximal model. For each analysis the minimal adequate model (parameters \pm 1 SE) is shown. PEGca $=$ perennial grass cover abundance; PEG-ht $=$ weighted mean height of the perennial grasses; W$\alpha=$ total vegetation William's $\alpha$ diversity; tGspp $=$ total grass species.

\begin{tabular}{llll}
\hline $\begin{array}{l}\text { Explanatory } \\
\text { variable }\end{array}$ & Deviance & F & Significance \\
\hline
\end{tabular}

\begin{tabular}{|c|c|c|c|}
\hline \multirow{2}{*}{\multicolumn{4}{|c|}{ a) Sown pastures }} \\
\hline & & & \\
\hline W- $\alpha$ & 49404452.00 & 839070.18 & $* * *$ \\
\hline tGspp & 92.66 & 1.57 & $\overline{\text { n.s. }}$ \\
\hline PEG-ht & 56.30 & 0.94 & n.s. \\
\hline PEGca & 7.41 & 0.16 & n.s. \\
\hline \multicolumn{4}{|c|}{$\begin{array}{l}\log \mathrm{AGF}=-6.86( \pm 3.67)+7.63( \pm 0.009) \text { square-root } \\
\mathrm{W}-\alpha\end{array}$} \\
\hline \multicolumn{4}{|c|}{ Summer 1994} \\
\hline W- $\alpha$ & 12784937.00 & 22081065.63 & $* * *$ \\
\hline PEGca & 0.03 & 0.03 & $\overline{\text { n.s. }}$ \\
\hline tGspp & 1.59 & 4.56 & n.s. \\
\hline PEG-ht & 0.16 & 0.30 & n.s. \\
\hline \multirow{2}{*}{\multicolumn{4}{|c|}{$\log \mathrm{AGF}=0.41( \pm 0.34)+0.77( \pm 0.0002) \mathrm{W}-\alpha$}} \\
\hline & & & \\
\hline $\mathrm{W}-\alpha$ & 5956209.00 & 1641281.00 & $* * *$ \\
\hline tGspp & 0.47 & 0.10 & $\overline{\text { n.s. }}$ \\
\hline PEGca & 12.01 & 11.77 & n.s. \\
\hline PEG-ht & 0.62 & 0.44 & n.s. \\
\hline \multicolumn{4}{|c|}{$\log \mathrm{AGF}=1.085( \pm 0.85)+0.64( \pm 0.0005) \mathrm{W}-\alpha$} \\
\hline \multicolumn{4}{|c|}{ Summer 1995} \\
\hline $\mathrm{W}-\alpha$ & 3168376.00 & 264031.33 & *** \\
\hline tGspp & 38.01 & -35.19 & $\bar{*}$ \\
\hline PEG-ht & 36.69 & 33.97 & $*$ \\
\hline PEGca & 0.12 & 0.06 & n.s. \\
\hline $\log \mathrm{AGF}=$ & $39( \pm 0.63)+c$ & $7( \pm 0.0002)$ & -0.007 \\
\hline
\end{tabular}

b) Semi-natural pastures

\begin{tabular}{crrr} 
Spring 1994 & & & \\
W- $\alpha$ & 56059256.00 & 32976032.94 & $* * *$ \\
PEG-ht & 0.13 & 0.08 & n.s. \\
PEGca & 0.36 & 0.15 & n.s. \\
tGspp & 4.47 & 14.91 & n.s. \\
log AGF $=-0.6( \pm 0.51)+1.04( \pm 0.0002)$ & W- $\alpha$ \\
Summer 1994 & \multicolumn{4}{|}{} \\
W- $\alpha$ & 70528352.00 & 22040110.00 & $* * *$ \\
tGspp & 165.90 & 51.84 & $*$ \\
PEG-ht & 159.20 & -49.75 & $*$ \\
PEGca & 3.67 & 1.35 & n.s.
\end{tabular}

$\log \mathrm{AGF}=0.33( \pm 1.106)+1.73( \pm 0.00039) \mathrm{W}-\alpha+0.005$

$( \pm 0.0006) \log$ tGspp $-14.4( \pm 2.04) \log$ PEG-ht Autumn 1994

$\begin{array}{lrrc}\text { W- } \alpha & 21498240.00 & 24155325.84 & * * * \\ \text { tGspp } & 26.66 & 29.96 & * \\ \text { PEG-ht } & 26.61 & -29.90 & * \\ \text { PEGca } & 1.68 & 16.57 & \text { n.s. }\end{array}$

$\log \mathrm{AGF}=-0.01( \pm 0.65)+1.56( \pm 0.003) \mathrm{W}-\alpha+0.103$ $( \pm 0.0 .02) \log$ tGspp $-1.015( \pm 0.19)$ PEG-ht Summer 1995

$\begin{array}{lrrl}\text { W- } \alpha & 2176379.00 & 122959265.54 & * * * \\ \text { PEGca } & 6.87 & -387.97 & \text { ** } \\ \text { tGspp } & 6.56 & 370.45 & \frac{\text { ** }}{\text { n.s. }}\end{array}$

$\log \mathrm{AGF}=0.25( \pm 0.09)+1.22( \pm 0.0001) \mathrm{W}-\alpha-3.33( \pm$ $0.17) \log$ PEGca $+0.001( \pm 0.00007) \log$ tGspp

$\mathrm{n} . \mathrm{s} .=$ not significant; $* \mathrm{p}<0.05 ; * * \mathrm{p}<0.01 ; * * * \mathrm{p}<0.001$. Note: Probabilities underlined are significant after Bonferroni adjustment $\left(\alpha^{\prime}=0.0031\right)$. dance of invertebrate groups common in pastures, in three Azorean islands. Such relations may signal vegetation predictors of invertebrate densities. Three vegetation indices, single or in combination (total vegetation William's alpha diversity, "W- $\alpha$ "; perennial forb cover abundance, "PEFca"; perennial grass cover abundance, "PEGca") were found to predict arthropod abundances of specific groups (Tables 1-3; see also Fig. 1).

Although the total density of forb-feeders and webbuilding spiders differed between islands, a habitat effect was obtained for forb- and grass-feeding insect densities. The density of forb-feeders tracked the cover abundance of perennial forbs, with both variables having significant island and habitat effects. The same occurred with the grass-feeders and the cover abundance of perennial grasses, which displayed a habitat effect. Similarly, the diversity of grasses and grass-feeders were related to island and habitat.

However, the cover abundance of perennial grasses and their height index were not good predictors of the abundance of grass-feeders in either habitats. Here, alpha-diversity of the vegetation as a whole was the main predictor of the grass-feeding insect abundance. Taking into account that the reduction in structural complexity of the vegetation by grazing or cutting is known to have an effect on the densities of grass-feeders (Morris 1973, Gibson et al. 1992b), these results are difficult to interpret and probably reflect the poor predictive value of the height index in these pasture systems. This is, perhaps, not surprising since the Azorean pastures are grazed more frequently than those studied by these authors in the U.K. More regular grazing may cause further disruption to the relationship, and prevent the insects from tracking the vegetation so closely.

Grasses are architecturally not as complex as forbs (Lawton and Schroeder 1977, Tscharntke and Greiler 1995), but still host a variety of insect species. Indeed, grass-feeding species were the most abundant herbivores in the field sites (e.g. Anoscopus albifrons, Euscelidius variegatus, Muellerianella sp. a, Aptinothrips rufus). The reason that the abundance of grasses (PEGca) was not a good predictor of grass-feeder density may indicate that few species are specific to individual grass species (Brown et al. 1992).

Similarly plant-insect abundance patterns were found in the spring and autumn 1994 and in the summers 1994 and 1995 for forb-feeding insects in sown pastures. Vegetation diversity seemed to be a good predictor of the density of forb-feeders in the summers 1994 and 1995 , in both sown and semi-natural pastures. Moreover, there is a paucity of forb-feeding species in Pico, despite the availability of forb species (see also Borges and Brown 1999). For the forb-feeding insects, both the cover abundance of forbs and the alpha-diversity of the vegetation were good predictors of forb-feeding insect density. 
For the web-building spiders, there was a consistently strong association between the abundance of this predatory assemblage and the cover abundance of

Table 3. Abundance of web-building spiders in sown (a) and semi-natural (b) pastures; analysis of deviance (ANODEV) table for multiple regression with step-wise omission of nonsignificant terms, beginning from the maximal model. For each analysis the minimal adequate model (parameters \pm 1 $\mathrm{SE}$ ) is shown. PEGca = perennial grass cover abundance $\mathrm{V}-\mathrm{ht}=$ weighted mean height of the total vegetation; W- $\alpha=$ total vegetation William's $\alpha$ diversity; Sprich $=$ the mean number of vascular plant species touching the point-quadrat pins.

\begin{tabular}{llll}
\hline $\begin{array}{l}\text { Explanatory } \\
\text { variable }\end{array}$ & Deviance & F & Significance \\
\hline
\end{tabular}

\begin{tabular}{lrrl}
\hline a) Sown pastures & & & \\
Spring 1994 & & & \\
PEGca & 100.10 & 720.14 & $* * *$ \\
W- $\alpha$ & 1.79 & -12.84 & $*$ \\
Sprich & 0.05 & 0.24 & n.s. \\
V-ht & 0.11 & 0.43 & n.s.
\end{tabular}

$\log$ AWBS $=-0.096( \pm 0.2)+1.69( \pm 0.06)$ PEGca -0.76

$( \pm 0.21)$ square-root $\mathrm{W}-\alpha$ Summer 1994

$\begin{array}{lrrl}\text { PEGca } & 12770071.00 & 2029250.12 & * * * \\ \text { W- } \alpha & 10.48 & 2.14 & \text { n.s. } \\ \text { Sprich } & 10.79 & 5.54 & \text { n.s. } \\ \text { V-ht } & \text { Aliased } & 0.00 & \text { n.s. }\end{array}$

$\log$ AWBS $=2.51( \pm 1.12)+0.77( \pm 0.0005)$ PEGca

Autumn 1994

$\begin{array}{lrrr}\text { PEGca } & 5954213.00 & 29534786.71 & * * * \\ \text { V-ht } & 0.47 & 3.35 & \text { n.s. } \\ \text { Sprich } & 0.11 & 0.96 & \text { n.s. } \\ \text { W- } \alpha & 0.11 & 0.92 & \text { n.s. } \\ \text { og AWBS }=1.26 & ( \pm 0.2)+0.64 & ( \pm 0.0001) & \text { PEGca } \\ \text { ummer } 1995 & & & \\ \text { PEGca } & 10.93 & 130.12 & * * \\ \text { W- } \alpha & 3.99 & -47.44 & * \\ \text { Sprich } & 3.69 & 43.89 & * \\ \text { V-ht } & 0.06 & 0.62 & \text { n.s. }\end{array}$

$\log$ AWBS $=0.96( \pm 0.2)+0.76(+0.06)$ PEGca- $0.82( \pm$ $0.12) \mathrm{W}-\alpha+0.45( \pm 0.07) \log$ Sprich

b) Semi-natural pastures

Spring 1994

$\begin{array}{lrrl}\text { PEGca } & 27.40 & 25.28 & * \\ \text { W- } \alpha & 23.44 & 21.62 & * \\ \text { V-ht } & 2.21 & 4.24 & \text { n.s. } \\ \text { Sprich } & \text { Aliased } & 0.00 & \text { n.s. }\end{array}$

$\log$ AWBS $=-0.04( \pm 0.67)+0.54( \pm 0.1)$ PEGca +95

$( \pm 0.1)$ square-root $\mathrm{W}-\alpha$

$\begin{array}{lrrl}\text { Summer 1994 } & & & \\ \text { PEGca } & 187.00 & 138.83 & * * \\ \text { W- } \alpha & 49.71 & -36.90 & * * \\ \text { Sprich } & 3.48 & 12.53 & \text { n.s. } \\ \text { V-ht } & \text { Aliased } & 0.00 & \text { n.s. } \\ \text { Autumn 1994 } & & & * * * \\ \text { W- } \alpha & 1698664.00 & 418906.04 & * * \\ \text { PEGca } & 74.81 & 18.45 & * \\ \text { Sprich } & 3.30 & 0.75 & \text { n.s. } \\ \text { V-ht } & \text { Aliased } & 0.00 & \text { n.s. } \\ \text { Summer } 1995 & & & \\ \text { PEGca } & 31667642.00 & 14593383.41 & * * * \\ \text { V-ht } & 5.68 & 15.15 & \text { n.s. } \\ \text { W- } \alpha & 2.65 & 5.70 & \text { n.s. } \\ \text { Sprich } & \text { Aliased } & 0.00 & \text { n.s. } \\ \text { log AWBS }=-1.95( \pm 0.66)+1.22 & ( \pm 0.0003) & \text { PEGca }\end{array}$

n.s. $=$ not significant; ${ }^{*} \mathrm{p}<0.05 ; * * \mathrm{p}<0.01 ; * * * \mathrm{p}<0.001$

Note: Probabilities underlined are significant after Bonferroni adjustment $\left(\alpha^{\prime}=0.0031\right)$.
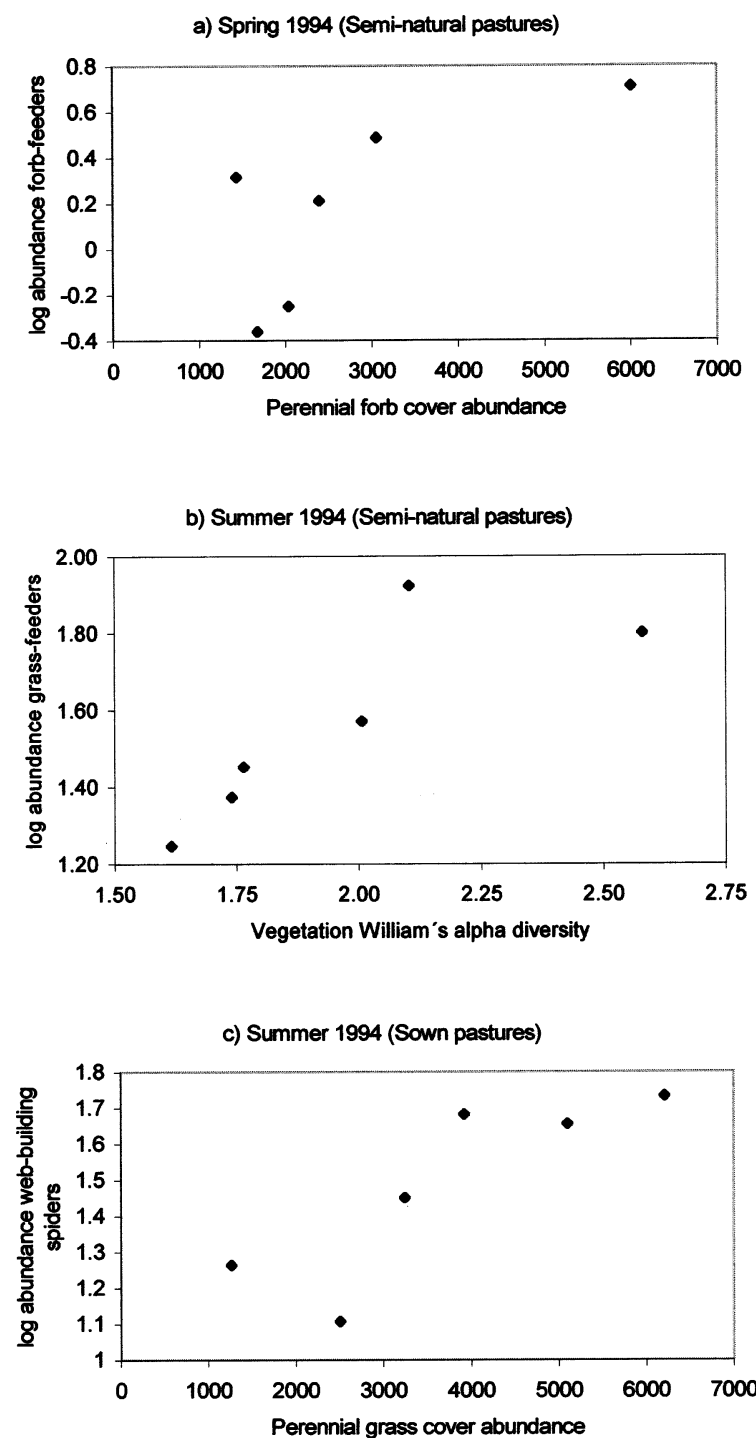

Fig. 1. Scatter plots of the relationships between: a) log abundance of forb-feeding insects and the perennial forb cover abundance in the semi-natural pastures (spring 1994); b) log abundance of grass-feeding insects and total vegetation William's $\alpha$ diversity in the semi-natural pastures (summer 1994); c) $\log$ abundance of web-building spiders and the perennial grass cover abundance in the sown pastures (summer 1994).

perennial grasses. Several inter-related mechanisms may be involved in causing more web-building spiders to occur in dense and structurally diverse grass swards. These include living space, for web attachment, shelter and prey, which will be greater in structurally complex habitats.

Such relationships have obvious implications in terms of pasture management. Spiders are well known biological control agents in agroecosystems, needing a complex sward architecture (Uetz 1991, Gibson et al. 1992a, Curry 1994, Wise 1995). Grazing reduces sward struc- 
tural complexity and also spider numbers (Gibson et al. 1992a, Curry 1994). In the present study, the density of spiders was determined three to four weeks after a grazing event, following some regrowth of the vegetation. As the spider density was related to the abundance of perennial grasses, this implies that management favouring a diverse and complex perennial grass sward also favours the assemblage of web-building spiders and consequently the biological control of potentially damaging phytophagous insects.

Other studies (see Brown and Gange 1989, Brown 1991a, b) have considered the weighted mean height index (Height) to be a reliable measure of habitat structure. In the present work, however, this index (e.g. V-ht, PEF-ht and PEG-ht) was seldom a good predictor of the density of the three assemblages studied. Moreover, these measures of vegetation height showed a significant sampling event effect, but no island or habitat effects. Such a result implies that, for the two habitats under study, these indices are strongly dependent on the seasonal vegetation growth and are of less value as predictors of arthropod density. Another feature, peculiar to the Azores, is that vegetation grows very quickly. As such, there would be much temporal variability in the index, which would reduce its value as a predictor.

In summary, the various effects of pasture management may have profound effects on local arthropod assemblages. Important predator assemblages, such as the web-building spiders, seem to respond positively to a well developed and complex grass sward. However, grass-feeding insects also increase in diverse vegetation, creating a trade-off between having a diverse grass sward for web spider attachment and a less diverse grass sward to decrease the diversity and density of grass-feeding insects. The positive relationship between forb cover abundance and the abundance of forb-feeders implies that good pasture management, which avoids invasion by weedy forb species, is one way of decreasing herbivory by generalist feeders on legume species which are usually of great importance for cattle.

Acknowledgements - We are grateful to J. Lawton (Centre for Population Biology, Imperial College, Univ. of London) for reviewing earlier drafts. Special thanks to G. Masters (CABIBioscience, Silwood Park, U.K.) for his help in adapting the computer software necessary for the analysis of the pointquadrat data. E. Dias (DCA-UA), B. Oliveira (Dept de Biologia, UA), R. Gabriel (DCA-UA) and A. Morton (Dept of Biology, Imperial College, Univ. of London) helped with the identification of several vascular plant species. The arthropod morphospecies were identified by several taxonomists who also gave valuable advice on the feeding habits and colonization status of each species: Heteroptera (J. Ribes, Barcelona, Spain), Homoptera-Auchenorrhyncha (J. Hollier, Glebe, U.K.; J. A. Quartau, "Faculdade de Ciências de Lisboa", Portugal), Aphididae (F. Ilharco, "Estação Agronómica Nacional", Portugal), Thysanoptera (R. zur Strassen, "Forschungsinstitut und Naturmuseum Senckenberg", Frankfurt, Germany), Lepidoptera (V. Vieira, "Dept Biologia da Univ. dos Açores", Portugal), Chrysomelidae (D. Erber,
Giessen-Lahn, Germany), Curculionidae (R. Booth, International Institute of Entomology, London, U.K.) and Araneae (J. Wunderlich, Straubenhardt, Germany). To all them our sincere thanks. This research was funded by JNICT ("Junta Nacional de Investigação Científica e Tecnológica", Lisboa, Portugal) (Science Program-Ph.D. Grant BD-2706-93-RN) and the Azorean Agriculture Services (Secretaria Regional da Agricultura e Pescas).

\section{References}

Andow, D. A. 1991. Vegetational diversity and arthropod population response. - Annu. Rev. Ecol. Syst. 22: 561586.

Bach, C. E. 1980. Effects of plant diversity and time of colonization on an herbivore-plant interaction. - Oecologia 44: 319-326.

Borges, P. A. V. 1990. A checklist of Coleoptera from the Azores with some systematic and biogeographic comments. - Bol. Mus. Mun. Funchal 42: 87-136.

Borges, P. A. V. 1997. Pasture arthropod community structure in Azorean islands of different geological age. - Ph.D. thesis, Imperial College, Univ. of London.

Borges, P. A. V. 1999. Plant and arthropod species composition of sown and semi-natural pasture communities of three Azorean islands (S. Maria, Terceira and Pico). Arquipélago 17A: 1-21.

Borges, P. A. V. and Brown, V. K. 1999. Effect of island geological age on the arthropod species richness of Azorean pastures. - Biol. J. Linn. Soc. 66: 373-410.

Brown, V. K. 1991a. The importance of habitat structure in the maintenance of insect species diversity. - In: Pineda, F. D. et al. (eds), Biological diversity. Fundación Ramón Areces, Madrid, pp. 49-55.

Brown, V. K. 1991b. The effects of changes in habitat structure during succession in terrestrial communities. - In: Bell, S. S., McCoy, E. D. and Mushinsky H. R. (eds), Habitat structure: the physical arrangement of objects in space. Chapman and Hall, pp. 141-168.

Brown, V. K. and Southwood, T. R. E. 1987. Secondary succession: patterns and strategies. - In: Gray, A. J., Crawley, M. J. and Edward, P. J. (eds), Colonization, succession and stability. Blackwell, pp. 315-337.

Brown, V. K. and Gange, A. C. 1989. Insect herbivory during early plant succession. - Oikos 54: 67-76.

Brown, V. K. and Gange, A. C. 1992. Secondary plant succession: how is it modified by insect herbivory? - Vegetatio 101: $3-13$.

Brown, V. K., Jepsen, M. and Gibson, C. W. D. 1988. Insect herbivory: effects on early old field succession demonstrated by chemical exclusion methods. - Oikos 52: 293302

Brown, V. K., Gibson, C. W. D. and Sterling, P. H. 1990. The mechanisms controlling insect diversity in calcareous grasslands. - In: Hillier, S. H., Walton, D. W. H. and Wells, D. A. (eds), Calcareous grasslands-ecology and management. Bluntisham Books, Huntingdon, pp. 79-87.

Brown, V. K., Gibson, C. W. D. and Kathirithamby, J. 1992. Community organization in leaf hoppers. - Oikos 65: 97-106.

Crawley, M. J. 1990. The relative importance of vertebrate and invertebrate herbivores in plant population dynamics. - In: Bernays E. A. (ed.), Insect plant interactions. CRC Press, Boca Raton, Florida, pp. 45-70.

Crawley, M. J. 1993. GLIM for Ecologists. - Blackwell.

Curry, J. P. 1994. Grassland invertebrates - ecology, influence on soil fertility and effects on plant growth. - Chapman and Hall.

De Keer, R. and Maelfait, J.-P. 1987. Life history of Oedothorax fuscus Blackwall, 1834. Araneae, Linyphiidae in a heavily grazed pasture. - Rev. D’Ecol. Biol. Sol 24: 171185. 
De Keer, R. and Maelfait, J.-P. 1988. Observations on the life cycle of Erigone atra Araneae, Erigoninae in a heavily grazed pasture. - Pedobiologia 32: 201-212.

Dennis, P., Young, M. R. and Gordon, I. J. 1998. Distribution and abundance of small insects and arachnids in relation to structural heterogeneity of grazed, indigenous grasslands. - Ecol. Entomol. 23: 253-264.

Denno, R. F. and Roderick, G. F. 1991. Influence of patch size, vegetation structure and host plant architecture on the diversity, abundance and life history styles of sapfeeding herbivores. - In: Bell, S. S., McCoy, E. D. and Mushinsky H. R. (eds), Habitat structure: the physical arrangement of objects in space. Chapman and Hall, pp. 169-196.

Gange, A. C. and Brown, V. K. 1989. Insect herbivory affects size variability in plant populations. - Oikos 56: 351-356.

Gardner, S. M. et al. 1995. The influence of habitat structure on arthropod diversity in Argentine semi-arid Chaco forest. - J. Veg. Sci. 6: 349-356.

Gibson, C. W. D. et al. 1987. Spring grazing by sheep: effects on seasonal change during early old field succession. Vegetatio 70: 33-43.

Gibson, C. W. D., Hambler, C. and Brown, V. K. 1992a. Changes in spider Araneae assemblages in relation to succession and grazing management. - J. Appl. Ecol. 29: $133-142$.

Gibson, C. W. D. et al. 1992b. The response of invertebrate assemblies to grazing. - Ecography 15: 166-176.

Good, J. A. and Giller, P. S. 1991. The effect of cereal and grass management on staphylinid Coleoptera assemblages in south-west Ireland. - J. Appl. Ecol. 28: 810-826.

Haysom, K. A. and Coulson, J. C. 1998. The Lepidoptera fauna associated with Calluna vulgaris: effects of plant architecture on abundance and diversity. - Ecol. Entomol. 23: $377-385$.

Henderson, I. E. F. 1978. Assessing the effects of invertebrates on grassland productivity. - Sci. Proc. of the Roy. Dublin Soc., Ser. A 6: $121-130$

Huntly, N. 1991. Herbivores and the dynamics of communities and ecosystems. - Annu. Rev. Ecol. Syst. 22: 477-503.

Lawton, J. H. 1983. Plant architecture and the diversity of phytophagous insects. - Annu. Rev. Entomol. 28: 23-39.

Lawton, J. H. and Schroeder, D. 1977. The effects of plant type, size of geographical range and taxonomic isolation on number of insect species associated with British plants. - Nature 265: 137-140.

Lawton, J. H. and Strong, D. R. 1981. Community patterns and competition in folivorous insects. - Am. Nat. 18: 317-338.

Morris, M. G. 1973. The effects of seasonal grazing on the Heteroptera and Auchenorhyncha Hemiptera of chalk grassland. - J. Appl. Ecol. 10: 761-780.

Morris, M. G. 1990a. The Hemiptera of two sown calcareous grasslands. I. Colonization and early succession. - J. Appl. Ecol. 27: 367-378
Morris, M. G. 1990b. The Hemiptera of two sown calcareous grasslands. II. Differences between treatments. - J. Appl. Ecol. 27: 379-393.

Morris, M. G. 1990c. The Hemiptera of two sown calcareous grasslands. III. Comparisons with the Auchenorhyncha faunas of other grasslands. - J. Appl. Ecol. 27: 394-409.

Roberts, M. J. 1995. Collins field guide - spiders of Britain and northern Europe. - Harper Collins Publishers, London.

Root, R. B. 1973. Organization of a plant-arthropod association in simple and diverse habitats: the fauna of collards Brassica oleracea. - Ecol. Monogr. 43: 95-124.

Rushton, S. P., Luff, M. L. and Eyre, M. D. 1989. Effects of pasture improvement and management on the ground beetle and spider communities of upland grasslands. - J. Appl. Ecol. 26: 489-503.

Schluter, D. and Ricklefs, R. E. 1993. Species diversity - an introduction to the problem. - In: Ricklefs, R. E. and Schluter, D. (eds), Species diversity in ecological communities. Historical and geographical perspectives. Univ. of Chicago Press, pp. 1-10.

Siemann, E. et al. 1998. Experimental tests of the dependence of Arthropod diversity on plant diversity. - Am. Nat. 152: $738-750$

Southwood, T .R. E. 1978. Ecological methods. 2nd ed. Chapman and Hall.

Southwood, T. R. E., Brown, V. K. and Reader, P. M. 1979. The relationships of plant and insect diversities in succession. - Biol. J. Linn. Soc. 12: 205-216.

Stilling, P. 1988. Density-dependent processes and key factors in insect populations. - J. Anim. Ecol. 57: 581-593.

Stinson, C. S. A. and Brown, V. K. 1983. Seasonal changes in the architecture of natural plant communities and its relevance to insect herbivores. - Oecologia 56: 67-69.

Strong, D. R., Lawton, J. H. and Southwood, T. R. E. 1984. Insects on plants. Community patterns and mechanisms. Blackwell.

Tscharntke, T. and Greiler, H.-J. 1995. Insect communities, grasses and grasslands. - Annu. Rev. Entomol. 40: 535558

Uetz, G. W. 1991. Habitat structure and spider foraging. - In: Bell, S. S., McCoy, E. D. and Mushinsky H. R. (eds), Habitat structure: the physical arrangement of objects in space. Chapman and Hall, pp. 325-348.

Usher, M. B. 1978. The structure of, and processes in, grassland animal communities: an introduction. - Sci. Proc. Roy. Dublin Soc., Ser. A 6: 121-130.

Vieira, V. and Pintureau, B. 1993. Diversité comparée des Lépidotères (Insecta) dans les îles des Açores: revision avec de nouvelles données. - Arquipélago 11A: 107-112.

Wise, D. H. 1995. Spiders in ecological webs. - Cambridge Univ. Press.

Wunderlich, J. 1991. The spider fauna of the Macaronesian islands - taxonomy, ecology, biogeography and evolution. - Beitr. Araneolog. 1: 1-619. 


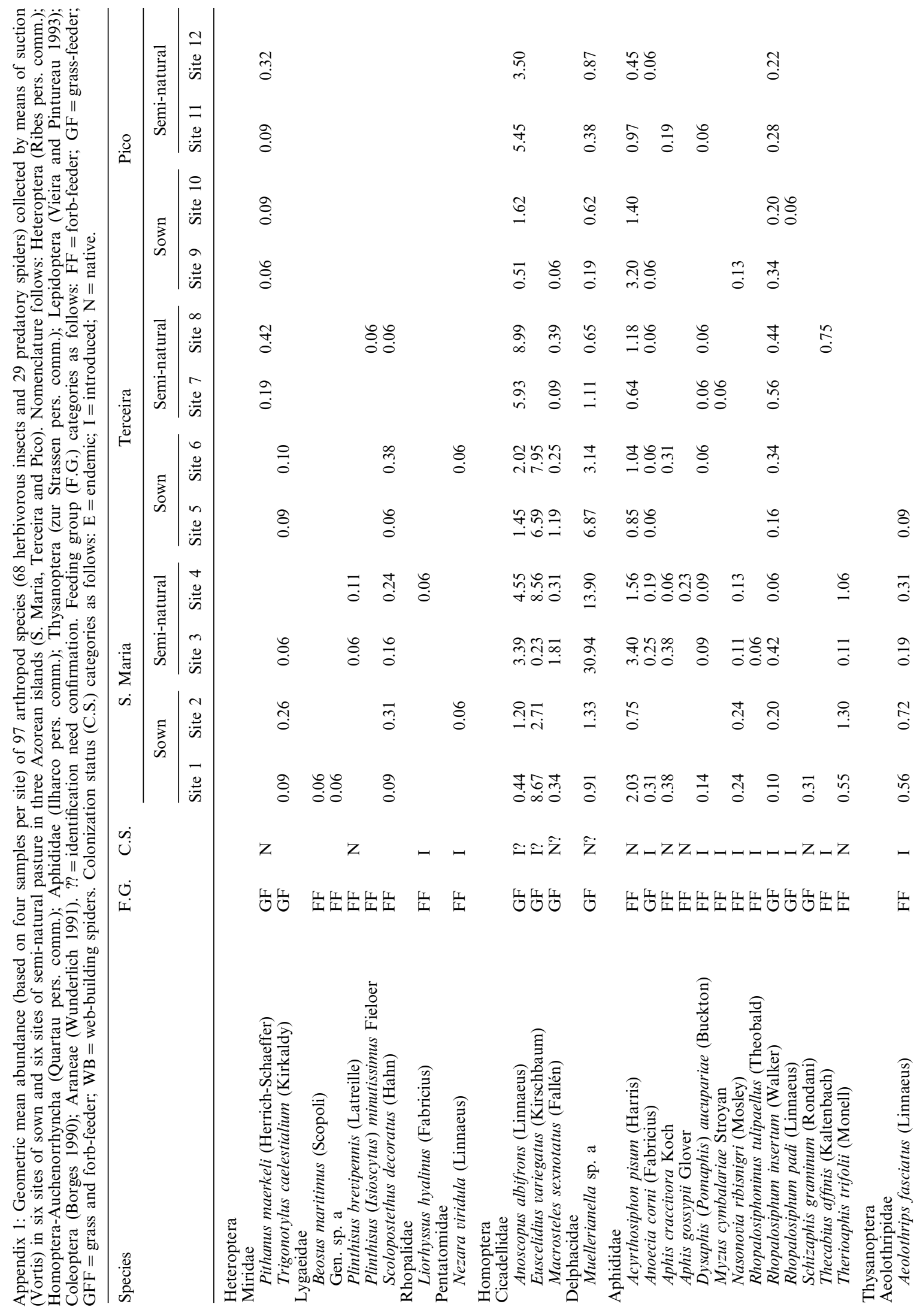




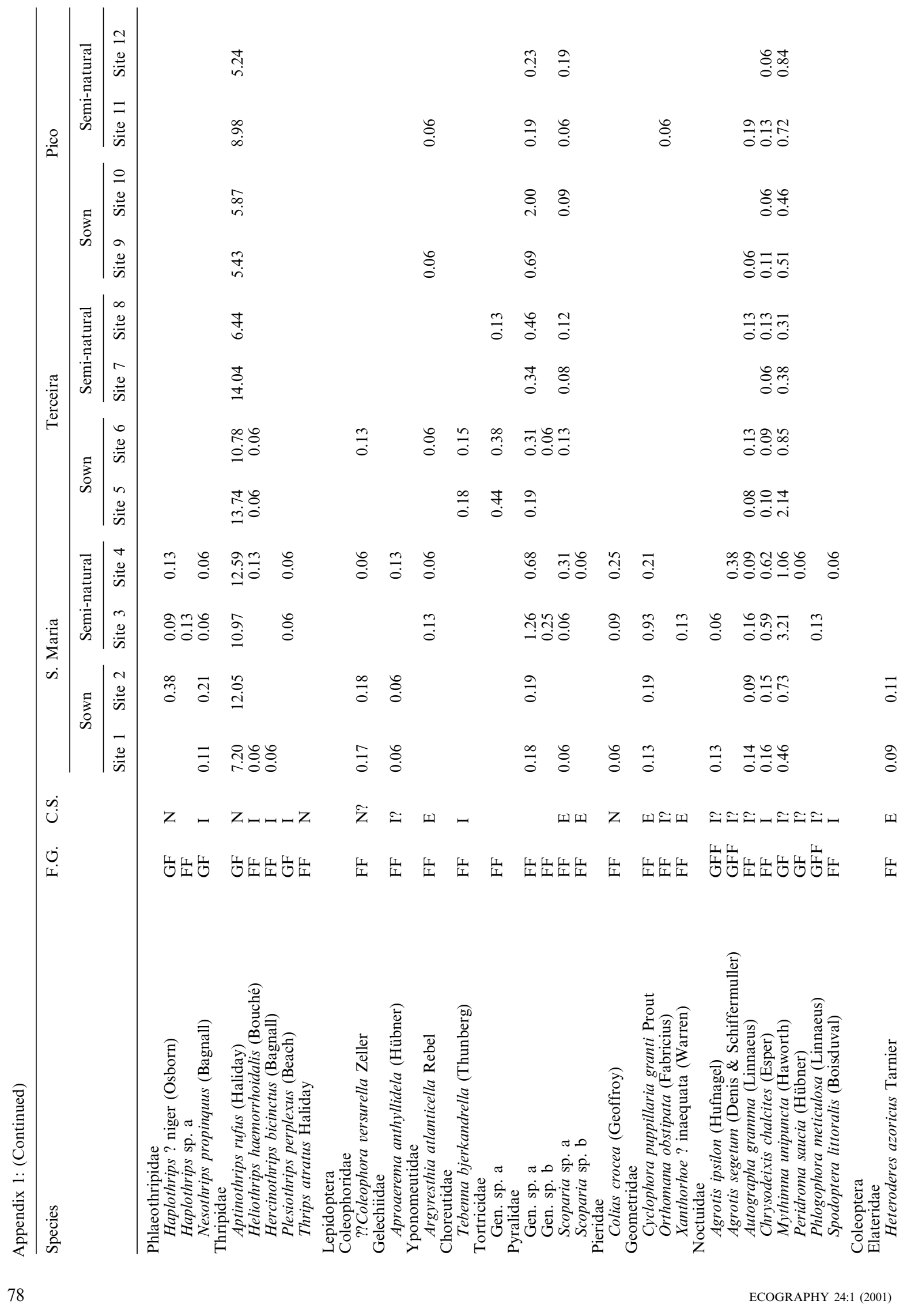




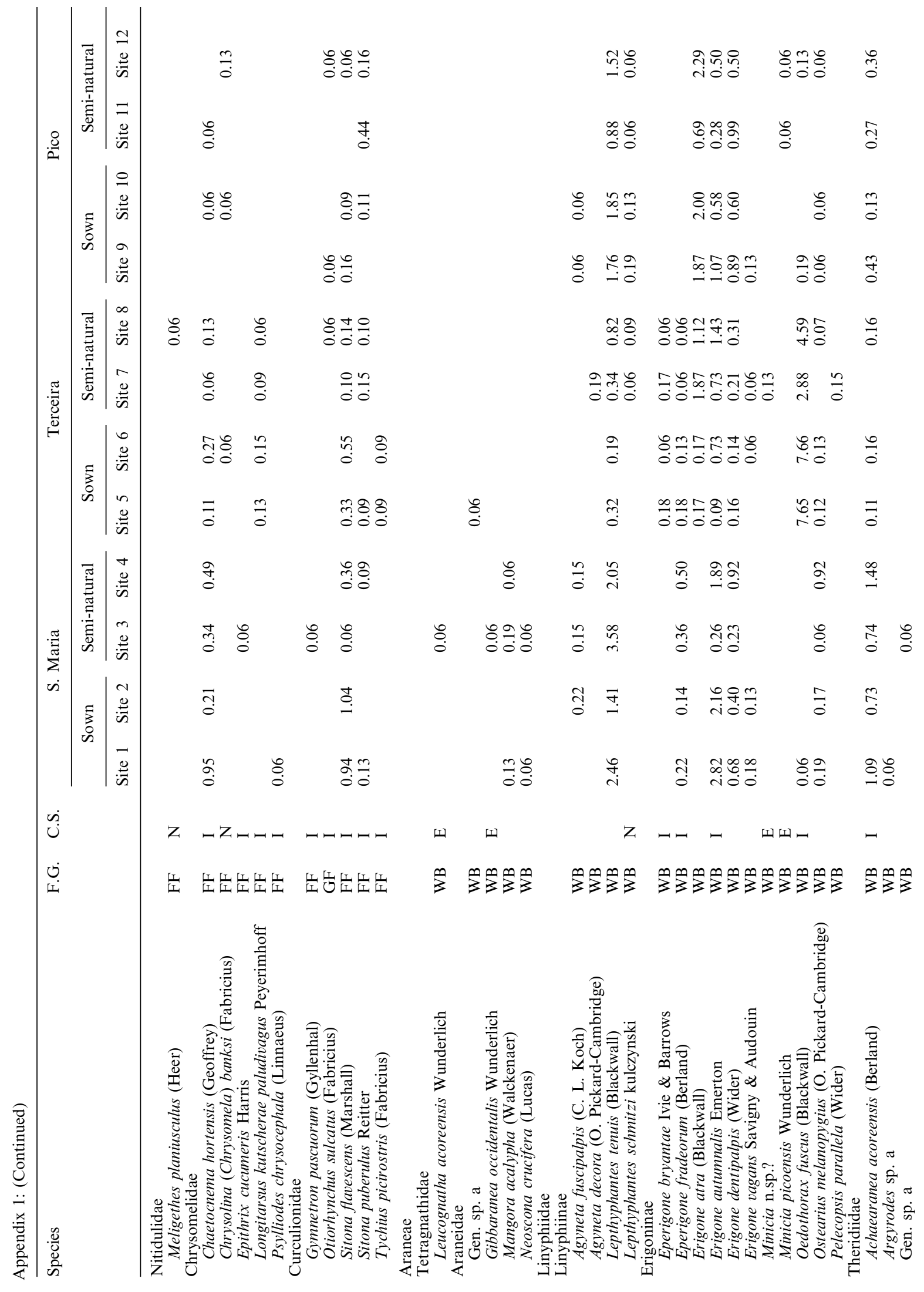




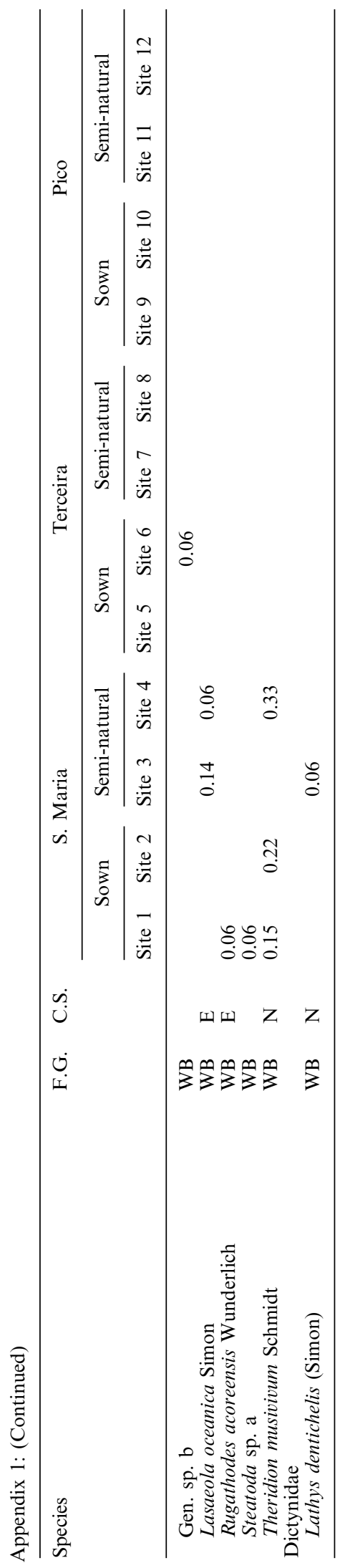




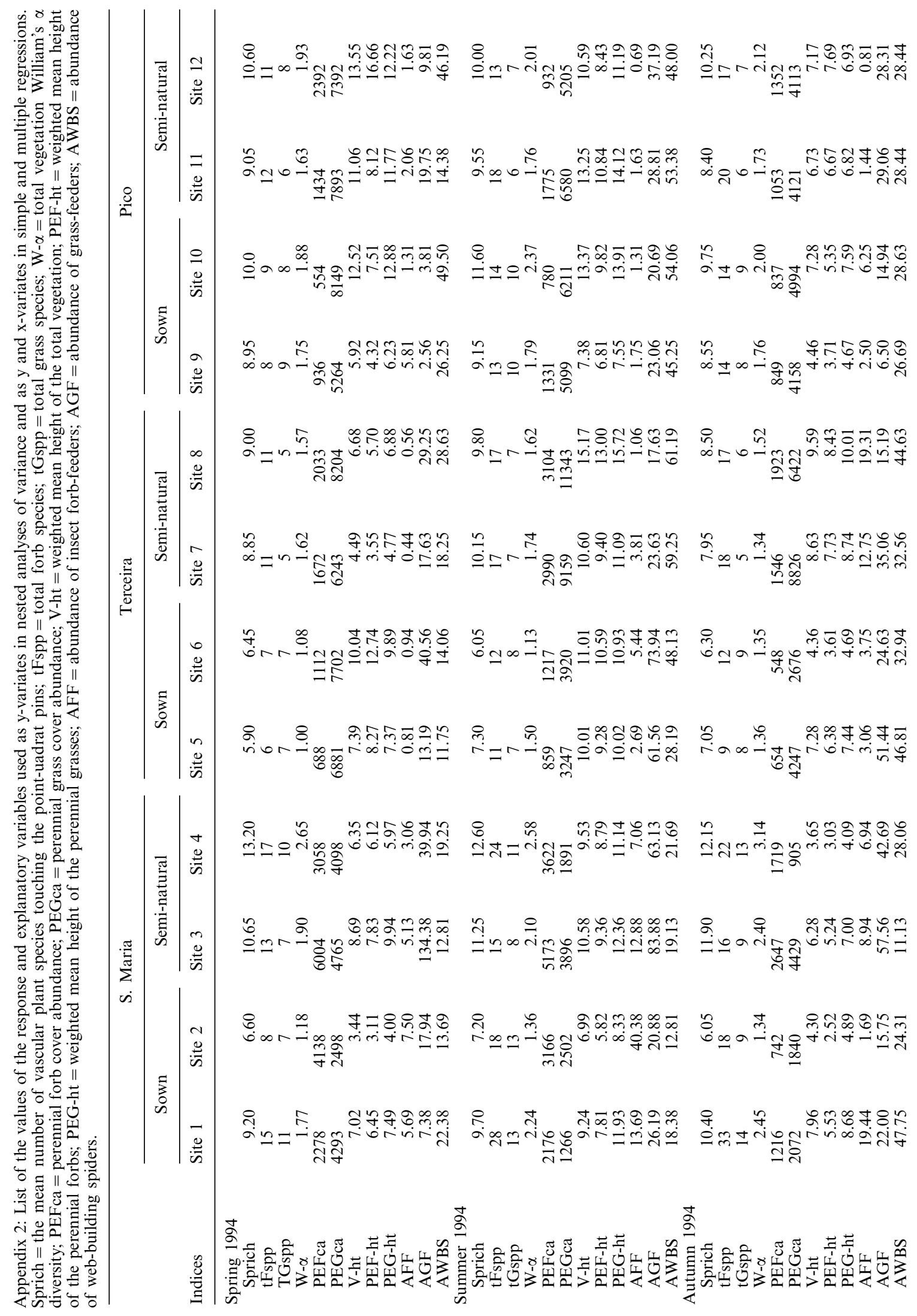




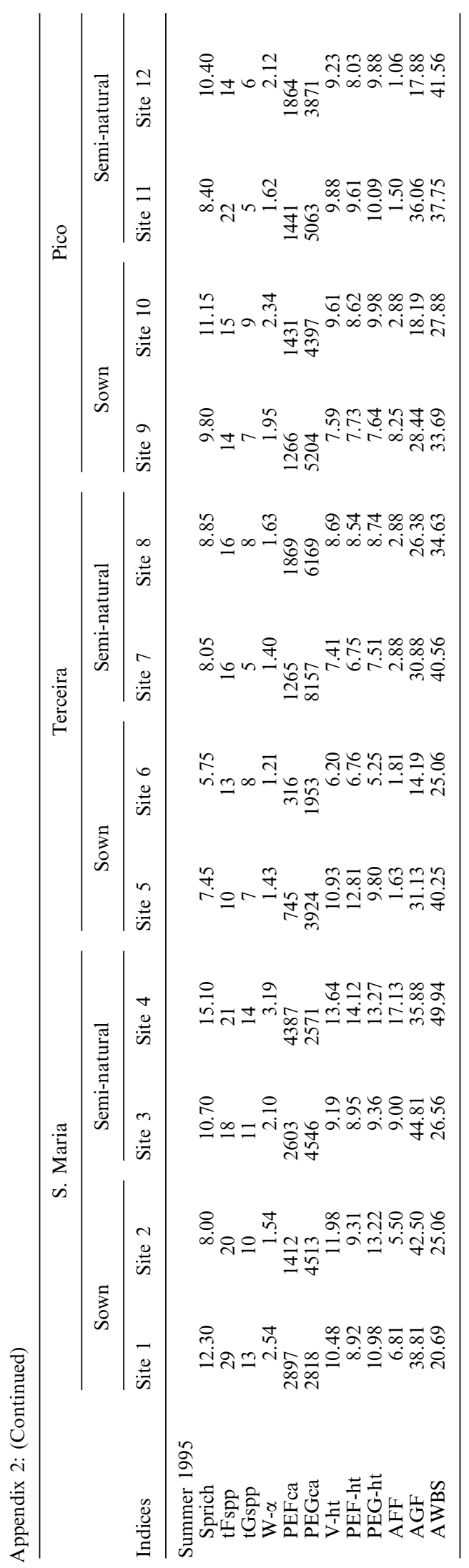

